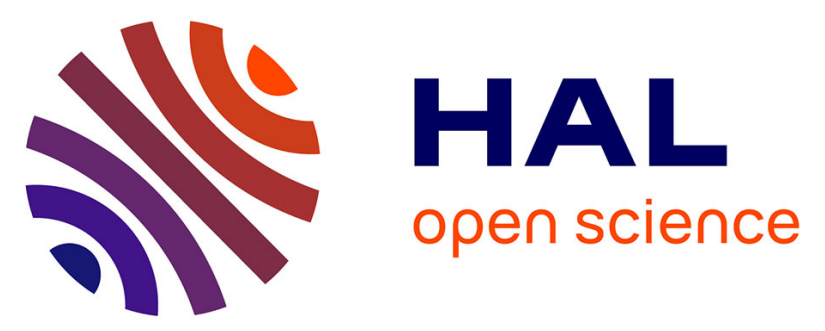

\title{
Honeydew honey as a potent antibacterial agent in eradication of multi-drug resistant Stenotrophomonas maltophilia isolates from cancer patients
}

\author{
Juraj Majtan, Lubica Majtanova, Jana Bohova, Viktor Majtan
}

\section{To cite this version:}

Juraj Majtan, Lubica Majtanova, Jana Bohova, Viktor Majtan. Honeydew honey as a potent antibacterial agent in eradication of multi-drug resistant Stenotrophomonas maltophilia isolates from cancer patients. Phytotherapy Research, 2010, 25 (4), pp.584. 10.1002/ptr.3304 . hal-00599844

\section{HAL Id: hal-00599844 \\ https://hal.science/hal-00599844}

Submitted on 11 Jun 2011

HAL is a multi-disciplinary open access archive for the deposit and dissemination of scientific research documents, whether they are published or not. The documents may come from teaching and research institutions in France or abroad, or from public or private research centers.
L'archive ouverte pluridisciplinaire HAL, est destinée au dépôt et à la diffusion de documents scientifiques de niveau recherche, publiés ou non, émanant des établissements d'enseignement et de recherche français ou étrangers, des laboratoires publics ou privés. 


\section{Honeydew honey as a potent antibacterial agent in eradication of multi-drug resistant Stenotrophomonas maltophilia isolates from cancer patients}

\begin{tabular}{|r|l|}
\hline Journal: & Phytotherapy Research \\
\hline Manuscript ID: & PTR-10-0640.R2 \\
\hline Wiley - Manuscript type: & Full Paper \\
\hline Date Submitted by the & 12 -Jul-2010 \\
\hline Complete List of Authors: & $\begin{array}{l}\text { Majtan, Juraj; Institute of Zoology Slovak Academy of Sciences; } \\
\text { Slovak Medical University, Department of Microbiology } \\
\text { Majtanova, Lubica; Slovak Medical University, Department of } \\
\text { Microbiology } \\
\text { Bohova, Jana; Institute of Zoology, Slovak Academy of Sciences } \\
\text { Majtan, Viktor; Slovak Medical University, Department of } \\
\text { Microbiology }\end{array}$ \\
\hline Keyword: & $\begin{array}{l}\text { Stenotrophomonas maltophilia, honey, multi-drug resistance, } \\
\text { antibacterial, manuka, honeydew }\end{array}$ \\
\hline
\end{tabular}

\section{S) ScholaroNE \\ Manuscript Central}




\section{Honeydew honey as a potent antibacterial agent in eradication of multi-drug resistant \\ Stenotrophomonas maltophilia isolates from cancer patients}

Short title: Honey in eradication of multi-drug resistant S. maltophilia

Juraj Majtan $^{1,2 *}$, Lubica Majtanova ${ }^{2}$, Jana Bohova $^{1}$ and Viktor Majtan ${ }^{2}$

${ }^{1}$ Institute of Zoology, Slovak Academy of Sciences, Dubravska cesta 9, 84506 Bratislava, Slovakia

${ }^{2}$ Department of Microbiology, Slovak Medical University, Limbova 12, 833 03, Bratislava, Slovakia

\footnotetext{
* Correspondence to: Dr. Juraj Majtan, Institute of Zoology, Slovak Academy of Sciences, Dubravska cesta 9, 84506 Bratislava, Slovakia, Tel.: +421-2-59302647, Fax.: +421-2-59302646, E-mail address: Juraj.Majtan@savba.sk
} 


\begin{abstract}
Multi-drug resistance in nosocomial pathogens is a continually evolving and alarming problem in health care units. Since ancient times, honey has been used successfully for treatment of broad spectrum of infections with no risk of resistance development.

In this study, we investigated the antibacterial activity of two natural honeys, namely honeydew and manuka, against 20 nosocomial multi-drug resistant Stenotrophomonas maltophilia (S. maltophilia) isolates from cancer patients. Antibiotic susceptibility test was carried out using disk diffusion method with 20 antibiotic disks. The antibacterial activity of honey was determined using a broth dilution method. The concentration of honey used in study was within the range of $3.75 \%$ to $25 \%(\mathrm{w} / \mathrm{v})$. All 20 clinical isolates were multi-drug resistant against 11 to 19 antibiotics. The MICs for honeydew honey ranged from $6.25 \%$ to $17.5 \%$, while those for active manuka honey ranged from $7.5 \%$ to $22.5 \%$. Honeydew honey had the lower MICs than manuka honey against 16 of tested isolates.

This study showed that Slovak honeydew honey has exceptional antibacterial activity against multi-drug resistant S. maltophilia isolates and was more efficient than manuka honey (UMF $15+)$. Honeydew honey with strong antibacterial activity could be used as a potential agent to eradicate of multi-drug resistance clinical isolates.
\end{abstract}

Keywords: honey, Stenotrophomonas maltophilia, multi-drug resistance, antibacterial, manuka, honeydew 


\section{Introduction}

Nowadays, Stenotrophomonas maltophilia has been considered, as an important opportunistic nosocomial pathogen in immune-competent individuals associated with different diseases that include both acute and chronic infections. Especially susceptible to S. maltophilia are immunecompromised patients, for example, patients with cancer (Khardori et al., 1990; Paez and Costa, 2008). S. maltophilia infection in hospitalized patients with cancer has significantly increased over the past two decades (Safdar and Rolston, 2007).

Very recent studies have revealed that $S$. maltophilia originating from external environment, the enteric tract or respiratory secretion may also participate in pathogenesis of persistent infections, particularly in chronic mucosal of skin surface infections (Dowd et al., 2008; Guggenheim et al., 2009; Tan et al., 2009). It has been found that incidence of S. maltophilia in burn wounds markedly increased in last decade (Guggenheim et al., 2009). In addition, Dowd et al. (2008) showed that $S$. maltophilia was a predominant bacterial type in biofilm associated with venous leg ulcers.

A characteristic feature of $S$. maltophilia is its low susceptibility to most agents currently used for treatment of human infections (Looney et al., 2009). Moreover, S. maltophilia exhibits highlevel resistance to a variety of structurally unrelated antibiotics, including $\beta$-lactams, quinolones, aminoglycosides, tetracycline, disinfectants and heavy metals (Zhang et al., 2000). The treatment of choice for S. maltophilia infections is still co-trimoxazole alone, or in combination with other agents. However, isolates resistant to this agent have already been reported (Nicodemo and Paez, 2007; Vartivarian et al., 1994). The increasing lack of antimicrobials with activity against $S$. maltophilia is of concern and there is an urgent need for new drugs. 
With increasing frequency modern medicine directs attention to natural products with antimicrobial activity and their use in clinical practice. The major arguments for implementing natural products such as honey are the low cost and absence of antimicrobial resistance risk. Honey can inhibit the growth wide range o bacteria, fungi, protozoa and viruses (Blair and Carter, 2005; Molan, 1992). Manuka honey derived from the floral source of Leptospermum scoparium in New Zealand has been claimed to have particularly high antimicrobial activity against various bacterial species (Allen et al., 1991; Lin et al., 2009; Lusby et al., 2005; Molan, 2006).

Beside two well-characterized major antibacterial factors in honey, hydrogen peroxide and high osmolarity; methylglyoxal (Adams et al., 2008; Mavric et al., 2008) and bee defensin-1 (Kwakman et al., 2010) also act as antibacterial substances. In addition, phenolic compounds found in dark honeys are partially responsible for antibacterial activity (Aljadi and Yusoff, 2003; Estevinho et al., 2008; Wahdan, 1998).

In our study, we investigate the antibacterial effect of Slovak honeydew honey against 20 nosocomial multi-drug S. maltophilia isolates from cancer patients and compare it with the activity of manuka honey.

\section{Materials and Methods}

\section{Bacterial isolates}


S. maltophilia clinical isolates $(n=20)$ from cancer patients were received from Department of Clinical Microbiology of National Institute for Oncology (Bratislava, Slovakia). These clinical isolates were collected during the period from December 2003 to March 2004.

\section{Honey samples}

The antibacterial activity of Slovak honeydew honey against 20 nosocomial clinical isolates of $S$. maltophilia was determined by comparison to the commercially available active manuka honey imported from New Zealand (Natur's Nectar, UMF 15+). Honeydew honey used in this study is monofloral honey derived from the floral source of Abies spp. localized in Bardejov (Slovakia) and was obtained from an apiary of Mr. Jozef Volansky (Medar s.r.o., Bardejov, Slovakia). To distinguish the effect of the antibacterial components of honey from any osmotic effect, artificial honey, a control solution with sugar content similar to that of natural honey, was also used for comparison. The artificial honey was prepared by dissolving $39 \mathrm{~g}$ D-fructose, $31 \mathrm{~g}$ Dglucose, $8 \mathrm{~g}$ maltose, $3 \mathrm{~g}$ sucrose and $19 \mathrm{~g}$ distilled water. All honey samples were stored in darkness at $2-5^{\circ} \mathrm{C}$ when not in use.

Fifty percent (w/v) stock solution of each type of honey was prepared by weighing $20 \mathrm{~g}$ of honey and bringing the volume up to $40 \mathrm{ml}$ of Trypton soya broth (TSB). Further dilutions of stock solution of natural honeys were done to obtain honey concentrations of $25 \%, 22.5 \%, 20 \%$, $17.5 \%, 15 \%, 12.5 \%, 11.25 \%, 10 \%, 8.75 \%, 7.5 \%, 6.25 \%, 5 \%$ and $3.75 \%$. Dilution range of $50 \%$, $25 \%$ and $12.5 \%$ of artificial honey was used.

\section{Antibiotic susceptibility test}


Antibiotic susceptibility was determined by the disk diffusion method with 20 antibiotic disks according to the criteria of the Clinical and Laboratory Standards Institute (CLSI) (Clinical and Laboratory Standards Institute, 2005) on Mueller-Hinton (MH) agar (Oxoid, Hampshire, UK). The following antimicrobial agents (disk content indicated in parentheses) were tested: amoxicillin-clavulanic acid $(20 / 10 \mu \mathrm{g})$, ampicillin $(10 \mu \mathrm{g})$, aztreonam $(30 \mu \mathrm{g})$, cefepime $(30 \mu \mathrm{g})$, cefotaxime $(30 \mu \mathrm{g})$, cefoxitin $(30 \mu \mathrm{g})$, cefpodoxime $(10 \mu \mathrm{g})$, ceftazidime $(30 \mu \mathrm{g})$, ceftriaxone (30 $\mu \mathrm{g})$, chloramphenicol $(30 \mu \mathrm{g})$, ciprofloxacin $(5 \mu \mathrm{g})$, cloxacillin $(5 \mu \mathrm{g})$, gentamicin $(10 \mu \mathrm{g})$, nalidixic acid $(30 \mu \mathrm{g})$, piperacillin-tazobactam $(100 / 10 \mu \mathrm{g})$, streptomycin $(10 \mu \mathrm{g})$, tetracycline $(30 \mu \mathrm{g})$, trimethoprim $(5 \mu \mathrm{g})$, sulfisoxazole $(250 \mu \mathrm{g})$ trimethoprim-sulfamethoxazole $(1.25 / 23.75$ $\mu \mathrm{g})$, E. coli ATCC 25922 was used as the control.

\section{Minimum inhibitory concentration assay}

Determination of MIC was conducted according to the recommendation of the CLSI (Clinical and Laboratory Standards Institute, 2003) with minor modification of using TSB instead of MH broth. Briefly, one bacterial colony was suspended in PBS buffer, $\mathrm{pH} 7.2$ and the turbidity of suspension was adjusted to $10^{8}$ colony forming unit $(\mathrm{cfu}) / \mathrm{mL}$ and diluted with medium to final concentration of $10^{7} \mathrm{cfu} / \mathrm{mL}$. Ten $\mu \mathrm{l}$ aliquots of suspension were inoculated to each well of sterile 96-well polystyrene plates (Sarstetd, Germany). The final volume in each well was 100 $\mu \mathrm{L}$, consisting of $90 \mu \mathrm{L}$ of sterile medium or diluted honey and $10 \mu \mathrm{L}$ of bacterial suspension. After $18 \mathrm{~h}$ of incubation at $37^{\circ} \mathrm{C}$, bacterial growth inhibition was determined by monitoring the 
optical density at $490 \mathrm{~nm}$. The MIC was defined as the lowest concentration of antibiotic inhibiting bacterial growth. All tests were performed in triplicate and were repeated three times.

\section{Results}

\section{Antibiotic susceptibility testing}

All 20 clinical isolates were multi-drug resistant against 11 to 19 antibiotics. Among all isolates, four strains $(20 \%)$ were resistant against co-trimoxazole (trimethoprim-sulfamethoxazole). The resistance against co-trimoxazole was associated with isolates resistant at least to 15 antibiotics. Ciprofloxacin resistance was found in two isolates (10\%). Antimicrobial resistance profiles of all isolates are summarized in Table 1.

\section{Determination of MIC of honey}

The MIC values of the two natural honeys and artificial honey are shown in Table 2. The MICs for honeydew honey ranged from $6.25 \%$ to $17.5 \%$, while those for active manuka honey ranged from $7.5 \%$ to $22.5 \%$. Honeydew honey had the lower MICs than manuka honey against 16 of tested S. maltophilia isolates, where the MIC values of honeydew honey were below $10 \%$ in 14 isolates. No difference was observed in the antibacterial activity of both natural honeys against two isolates. Artificial honey inhibited the growth of all isolates at concentration higher than $25 \%$. 


\section{Discussion}

S. maltophilia has emerged as an important pathogen, whose eradication is often problematic due to resistance to broad spectrum of antibiotics. When the administration of co-trimoxazole for the treatment of patients with $S$. maltophilia infections is not possible, there may be other effective alternative treatments using ciprofloxacin as a monotherapy or in combination with other antibiotics, or ticarcillin-clavulanate alone or in combination with other agents. An increasing trend of resistance to ciprofloxacin and emerging co-trimoxazole resistance in S. maltophilia was reported in last decade (Gales et al., 2001; San Gabriel et al., 2004). We found that 20\% of isolates used in this study were resistant to co-trimoxazole, an agent still recommended for treatment of $S$. maltophilia infections. In addition, $10 \%$ of isolates exhibited the resistance to ciprofloxacin, as a second therapeutic option. Novel or re-emerged antibacterial agents are urgently needed for treatment of infections caused by multi-drug resistant S. maltophilia. Honey could be a potential natural candidate to help eradicate of $S$. maltophilia infections.

It has been demonstrated that medical-grade manuka honey is effective against broad range of microorganisms including multi-resistant clinical strains (George and Cutting, 2007). Until now, it has not been shown that honey is able to inhibit the growth of multi-drug clinical $S$. maltophilia isolates. However, Tan et al. (2009) demonstrated that Malaysian tualang honey together with manuka honey (UMF 10+) with MIC of $10 \%(w / v)$ showed good antibacterial activity against $S$. maltophilia clinical strain with unknown antibiotic susceptibility profile.

Both Medihoney, a medical grade manuka honey and Revamil, a medical grade buckwheat honey are well-characterized honeys with pronounced healing properties. It has been documented that antibacterial activity of manuka honey directly originates from the 
methylglyoxal (Adams et al., 2008; Mavric et al., 2008). On the other hand, antibacterial bee defensin-1 has very recently been identified in Revamil and it substantially contributes to the antibacterial activity of honey (Kwakman et al., 2010). It remains to establish whether methylglyoxal and antibacterial bee peptide are also present in other natural honeys.

Along with methylglyoxal and defensin-1, the phenolic compounds in honey have been considered as potential antimicrobial agents (Gomez-Caravaca et al., 2006; Taormina et al., 2001). The honey phenolic compounds composition and consequent antibacterial and antioxidant capacity of honey depends on their floral sources. In present study, dark honeydew honey derived from the floral source of Abies spp. was used to investigate its bactericidal activity against multi-drug resistant S. maltophilia isolates. According to recent studies (Estevinho et al., 2008; Kwakman et al., 2010), we speculate that several non-peroxide factors, namely defensin-1 and phenolic compounds of honeydew honey participate in its strong antibacterial properties. Further detailed studies are needed to identification of components responsible for antibacterial properties of honeydew honey.

In conclusion, our results document that Slovak honeydew honey has exceptional antibacterial activity against multi-drug resistant $S$. maltophilia isolates from cancer patients. In addition, in the most cases it exhibited considerably stronger antibacterial activity than manuka honey and it could potentially be used as an alternative therapeutic agent against S. maltophilia infections.

\section{Acknowledgements}

We thank Mrs. Janka Zatkova for her technical assistance. This work was funded by the Operational Program Research and Development and co-financed with European Fund for 
Regional Development (EFRD). Grant: ITMS 26240220020 - "Establishment of biotherapeutic facility and technology proposal for production and development of bio-drugs".

\section{References}

1. Adams CJ, Boult CH, Deadman BJ, Farr JM, Grainger MNC, Manley-Harris M, Snow MJ. 2008. Isolation by HPLC and characterisation of the bioactive fraction of New Zealand manuka (Leptospermum scoparium) honey. Carbohydr Res 343: 651-659.

2. Aljadi AM, Yusoff KM. 2003. Isolation and identification of phenolic acids in Malaysian honey with antibacterial properties. Turk J Med Sci 33: 229-236.

3. Allen KL, Molan PC, Reid GM. 1991. A survey of the antibacterial activity of some New Zealand honeys. J Pharm Pharmacol 43: 817-822.

4. Blair SE, Carter DA. 2005. The potential for honey in the management of wounds and infections. J Australian Infect Control 10: 24-31.

5. Clinical and Laboratory Standards Institute. 2003. Methods for dilution of antimicrobial susceptibility tests for bacteria that growth aerobically, 6th edn. Approved standard M7-A6. CLSI/NCCLS M7-A6 Wayne (PA): The Institute.

6. Clinical and Laboratory Standards Institute. 2005. Performance standards for antimicrobial susceptibility testing; 15th informational supplement. CLSI/NCCLS M100-S15 Wayne (PA): The Institute.

7. Dowd SE, Sun Y, Secor PR, Rhoads DD, Wolcott BM, James GA, Wolcott RD. 2008. Survey of bacterial diversity in chronic wounds using Pyrosequencing, DGGE, and full ribosome shotgun sequencing. BMC Microbiol 8: 1-15. 
8. Estevinho L, Pereira AP, Moreira L, Dias LG, Pereira E. 2008. Antioxidant and antimicrobial effects of phenolic compounds extracts of Northeast Portugal honey. Food Chem Toxicol 46: 3774-3779.

9. Gales AC, Jones RN, Forward KR, Linares J, Sader HS, Verhoef J. 2001. Emerging importance of multidrug-resistant Acinetobacter species and Stenotrophomonas maltophilia as pathogens in seriously ill patients: geographic patterns, epidemiological features, and trends in the SENTRY Antimicrobial Surveillance Program (1997-1999). Clin Infect Dis 32: S104-S132.

10. George NM, Cutting KF. 2007. Antibacterial honey $\left(\right.$ Medihoney $\left.^{\mathrm{TM}}\right)$ : in vitro activity against clinical isolates of MRSA, VRE and other multiresistant gram-negative organisms including Pseudomonas aeruginosa. Wounds 19: 231-236.

11. Gomez-Caravaca AM, Gomez-Romero M, Arraez-Roman D, Segura-Carretero A, Fernandez-Gutierrez A. 2006. Advances in the analysis of phenolic compounds in products derived from bees. J Pharm Biomed Anal 41: 1220-1234.

12. Guggenheim M, Zbinden R, Handschin AE, Gohritz A, Altintas MA, Giovanoli P. 2009. Changes in bacterial isolates from burn wounds and their antibiograms: A 20-year study (1986-2005). Burns 35: 553-560.

13. Khardori N, Elting L, Wong E, B S, Bodey GP. 1990. Nosocomial infections due to Xanthomonas maltophilia (Pseudomonas maltophilia) in patients with cancer. Rev Infect Dis 12: $997-1003$.

14. Kwakman PH, te Velde AA, De Boer L, Speijer D, Vandenbroucke-Grauls CM, Zaat SA. 2010. How honey kills bacteria. FASEB J 24: in press. 
15. Lin SM, Molan PC, Cursons RT. 2009. The in vitro susceptibility of Campylobacter spp. to the antibacterial effect of manuka honey. Eur J Clin Microbiol Infect Dis 28: 339-344.

16. Looney WJ, Narita M, Muhlemann K. 2009. Stenotrophomonas maltophilia: an emerging opportunistic human pathogen. Lancet Infect Dis 9: 312-323.

17. Lusby PE, Coombes AL, Wilkinson JM. 2005. Bactericidal activity of different honeys against pathogenic bacteria. Arch Med Res 36: 464-467.

18. Mavric E, Wittmann S, Barth G, Henle T. 2008. Identification and quantification of methylglyoxal as the dominant antibacterial constituent of Manuka (Leptospermum scoparium) honeys from New Zealand. Mol Nutr Food Res 52: 483-489.

19. Molan PC. 1992. The antibacterial nature of honey. 1. The nature of the antibacterial activity. Bee World 73: 5-28.

20. Molan PC. 2006. The evidence supporting the use of honey as a wound dressing. Int J Low Extrem Wounds 5: 40-54.

21. Nicodemo AC, Paez JI. 2007. Antimicrobial therapy for Stenotrophomonas maltophilia infections. Eur J Clin Microbiol Infect Dis 26: 229-237.

22. Paez JI, Costa SF. 2008. Risk factors associated with mortality of infections caused by Stenotrophomonas maltophilia: a systematic review. J Hosp Infect 70: 101-108.

23. Safdar A, Rolston KV. 2007. Stenotrophomonas maltophilia: changing spectrum of a serious bacterial pathogen in patients with cancer. Clin Infect Dis 45: 1602-1609.

24. San Gabriel P, Zhou J, Tabibi S, Chen Y, Trauzzi M, Saiman L. 2004. Antimicrobial susceptibility and synergy studies of Stenotrophomonas maltophilia isolates from patients with cystic fibrosis. Antimicrob Agents Chemother 48: 168-171. 
25. Tan HT, Rahman RA, Gan SH, Halim AS, Hassan SA, Sulaiman SA, Kirnpal-Kaur B. 2009. The antibacterial properties of Malaysian tualang honey against wound and enteric microorganisms in comparison to manuka honey. BMC Complement Altern Med 9: 34.

26. Taormina PJ, Niemera BA, Beuchat LR. 2001. Inhibitory activity of honey against foodborne pathogens as influenced by the presence of hydrogen peroxide adn level of antioxidant power. Int J Food Microbiol 69: 217-225.

27. Vartivarian SE, Anaissie EJ, Bodey GP, Sprigg H, Rolston KV. 1994. A changing pattern of susceptibility of Xanthomonas maltophilia to antimicrobial agents: implications for therapy. Antimicrob Agents Chemother 38: 624-627.

28. Wahdan HA. 1998. Causes of the antimicrobial activity of honey. Infection 26: 26-31.

29. Zhang L, Li XZ, Poole K. 2000. Multiple antibiotic resistance in Stenotrophomonas maltophilia: involvement of a multidrug efflux system. Antimicrob Agents Chemother 44: 287-293. 
Table 1. Incidence of antibiotic resistance in 20 clinical isolates of S. maltophilia

\begin{tabular}{|c|c|}
\hline $\begin{array}{c}\text { Isolate } \\
\text { No. } \\
(\mathrm{n}=20)\end{array}$ & Antibiogram \\
\hline $57 / 03$ & A AMC ATM CPD CRO CTX FEP FOX OB TMP TZP \\
\hline $58 / 03$ & A AMC ATM C CAZ CPD CRO CTX FEP FOX NAL OB S Su SXT TMP TZP \\
\hline $122 / 03$ & A AMC ATM CPD CRO CTX FEP FOX NAL OB S Su TMP TZP \\
\hline $241 / 03$ & A AMC ATM CAZ CPD CRO CTX FEP FOX OB TMP TZP \\
\hline $255 / 03$ & A AMC ATM C CIP CPD CRO CTX FEP FOX G NAL OB S Su SXT T TMP TZP \\
\hline $269 / 03$ & A AMC ATM CPD CRO CTX FEP FOX OB TMP TZP \\
\hline $325 / 03$ & A AMC ATM C CAZ CIP CPD CRO CTX FEP FOX G NAL OB S Su SXT T TMP \\
\hline $368 / 03$ & A AMC ATM CPD CRO CTX FEP FOX OB Su TMP TZP \\
\hline $388 / 03$ & A AMC ATM C CPD CRO CTX FEP FOX OB TMP TZP \\
\hline $389 / 03$ & A AMC ATM CAZ CPD CRO CTX FEP FOX OB TMP TZP \\
\hline $509 / 03$ & A AMC ATM CPD CRO CTX FEP FOX OB TMP TZP \\
\hline $996 / 03$ & A AMC ATM CPD CRO CTX FEP FOX NAL OB TMP TZP \\
\hline $1444 / 03$ & AMC ATM CAZ CPD CRO CTX FEP FOX OB Su TMP TZP \\
\hline $3354 / 03$ & A AMC ATM CPD CRO CTX FEP FOX OB TMP TZP \\
\hline $47 / 04$ & A AMC ATM CPD CRO FEP FOX OB S Su TMP TZP \\
\hline $287 / 04$ & A AMC ATM CAZ CPD CRO CTX FEP FOX OB S Su TMP TZP \\
\hline $300 / 04$ & A AMC ATM C CAZ CPD CRO CTX FEP FOX OB Su SXT TMP TZP \\
\hline $846 / 04$ & A AMC ATM CPD CRO CTX FEP FOX OB Su TMP TZP \\
\hline $993 / 04$ & A AMC ATM CPD CRO CTX FEP FOX OB Su TMP TZP \\
\hline & 14 \\
\hline
\end{tabular}


$999 / 04$ A AMC ATM CPD CRO CTX FEP FOX OB TMP TZP

\begin{abstract}
A, ampicillin; AMC, amoxicillin-clavulanic acid; ATM; aztreonam; C, chloramphenicol; CAZ, ceftazidime; CIP, ciprofloxacin; CPD, cefpodoxime; CRO, ceftriaxone; CTX, cefotaxime; FEP, cefepime; FOX, cefoxitin; G, gentamicin; OB, cloxacillin; NAL, nalidixic acid; S, streptomycin; Su, sulfisoxazole; SXT, trimethoprim-sulfamethoxazole; T, tetracycline; TMP, trimethoprim; TZP, piperacillin-tazobactam
\end{abstract}


Table 2. Minimum inhibitory concentration (\%) of different honeys towards S. maltophilia clinical isolates

\section{S. maltophilia strain}

Type of honey

$(n=20)$

Honeydew

Manuka (UMF 15+)

Artificial

7.5

15

50

$58 / 03$

7.5

15

25

$122 / 03$

7.5

11.25

50

241/03

7.5

15

25

$255 / 03$

10

20

50

269/03

7.5

15

50

325/03

8.75

17.5

50

$368 / 03$

7.5

15

50

$388 / 03$

7.5

11.25

25

$389 / 03$

6.25

11.25

25

509/03

7.5

15

25

996/03

7.5

15

25

1444/03

7.5

15

50

$3354 / 03$

7.5

15

50

$47 / 04$

12.5

11.25

50

$287 / 04$

8.75

11.25

25

$300 / 04$
7.5

25 
$846 / 04$

15

10

50

993/04

17.5

17.5

50

994/04

17.5

17.5

50 